\title{
Metabolic differentiation of diploid and triploid European sea bass juveniles
}

\author{
Cosmas Nathanailides 1 - Dimitris Klaoudatos $\cdot$ Costas Perdikaris • \\ Spyros Klaoudatos $\cdot$ Markos Kolygas $\cdot$ Fotini Athanassopoulou
}

Received: 28 November 2018/ Accepted: 6 June 2019/Published online: 14 June 2019

(C) The Author(s) 2019

\begin{abstract}
The effects of triploidy were studied on indices of growth and metabolism in juvenile European sea bass. Ploidy affected flesh quality of Dicentrachus labrax, as protein and water contents were significantly higher in triploid than in diploid fish and triploid fish exhibited significantly lower lipid content. Compared to $2 n$ fish, triploid fish exhibited $53.4 \%$ and $28.6 \%$ more DNA and RNA, respectively, $17.2 \%$ higher RNA/DNA ratio and $28.7 \%$ more protein/DNA ratio. The activities of the aerobic metabolism enzyme CCO and the glycolytic LDH of the muscle tissue were significantly higher in the triploid fish. Nevertheless, the ratio of these two enzymes was lower in the triploids, indicating metabolic difference in the potential for aerobic metabolism. The increased activity of LDH may reflect a potential shift towards anaerobic metabolism required under demanding conditions, for example, during burst swimming, confirming the effects of ploidy on the aerobic swimming capacity of fish. The increased CCO activity of triploids observed in the present work indicates an effect of ploidy on the capacity for aerobic metabolism of triploid fish.
\end{abstract}

Keywords Aquaculture $\cdot$ Metabolism $\cdot$ Triploid $\cdot$ Sea bass $\cdot$ Polyploidy

\section{Introduction}

The nucleic acid content and the concentration of metabolic enzymes are widely used biochemical indices of aerobic and anaerobic metabolism and fish growth. The total DNA of a tissue can reflect the number of cells,

C. Nathanailides $(\bowtie)$

Faculty of Agriculture, University of Ioannina, 47100 Arta, Greece

e-mail: cosmasfax@yahoo.com

D. Klaoudatos

Hellenic Centre for Marine Research, Institute of Marine Biology, Biotechnology and Aquaculture, Agios Kosmas,

16777 Hellinikon, Athens, Greece

Present Address:

D. Klaoudatos - S. Klaoudatos

Department of Ichthyology and Aquatic Environment, University of Thessaly, Fytokou Street, 38446 Volos, Greece

C. Perdikaris

Department of Fisheries, Regional Unit of Thesprotia, Region of Epirus, 46100 Igoumenitsa, Greece

M. Kolygas - F. Athanassopoulou

Laboratory of Ichthyology and Ichthyopathology, Veterinary School, University of Thessaly, 43100 Karditsa, Greece 
but is expected to be higher in triploids (Cimino 1974). RNA content may vary according to cell size and tissue growth (Goolish et al. 1984; Mittakos et al. 2012) and can be used as an index of somatic growth rate in diploid and triploid fish (Arndt et al. 1994; Suresh and Sheehan 1998). The ratio of RNA/DNA and protein/ DNA can provide some information for the nutritional status and the protein metabolism of growing fish, but these ratios should be used with caution due to the increased DNA content of $3 n$ fish (Suresh and Sheehan 1998).

The aerobic and anaerobic capacity of cells can be reflected on the mitochondrial enzyme activity and on enzymes involved in the anaerobic breakdown of glycogen in fish muscle. Cytochrome c oxidase (CCO) is a mitochondrial enzyme which exhibits higher activity in fast growing fish (Houlihan et al. 1993) and its activity can be used as an indicator of the aerobic metabolism of fish muscle (Goolish and Adelman 1987), whereas the activity of the glycolytic enzyme lactate dehydrogenase (LDH) often correlates well with reliance upon anaerobic glycolysis (Hochachka and Mommsen 1983; Guderley and Gawlicka 1992) and contributes to the thermal modulation of pyruvate metabolism (Somero 1973).

Triploid fish exhibit some physiological and anatomical differences in the size and shape of their cells. The cells and nucleus of triploids are larger in size than those of their diploid counterparts (Benfey 1999; Maxime 2008), but the total volume of some organs may remain unchanged, possibly through the reduction in the number of cells. Ploidy can affect the energy metabolism of growing fish (Gonçalves et al. 2018) and their tolerance to poor water quality (Benfey 1999) indicating reduced tolerance to hypoxic conditions and the aerobic metabolism of triploid fish. Increased size of cells may result in reduced surface-to-volume ratio reduced intracellular diffusion of oxygen and exchange of metabolic molecules. In turn, the aerobic and anaerobic capacity of triploids and diploids may vary, with possible consequences for their metabolic efficiency and growth. For example, triploids may have fewer and larger axial muscle cells and reduced aerobic swimming capacity (Virtanen et al. 1990). Larger muscle cells may be more suited for anaerobic burst swimming and their capacity for anaerobic glycolysis of fish can be reflected on increased activity of LDH (Somero and Childress 1980; Saavedra et al. 2016).

In addition to changes in enzyme activity, other adaptive physiological responses may be employed to enhance oxygen delivery. For example, at low temperatures, oxygen diffusion is impaired and fish respond to this by increasing capillarisation (Egginton and Sidell 1989), which is accompanied by increased mitochondrial enzyme content (Nathanailides 1996) at least partially compensating for limited oxygen diffusion and aerobic metabolism. In fact, at cold temperatures, triploid fish can maintain higher metabolic rates than diploids, but this difference is reversed at warm temperatures, indicating some significant differences between $2 n$ and $3 n$ fish in their capacity for adaptive physiological responses to environmental changes (Atkins and Benfey 2008).

The specific aim of the present work was to investigate differences in the metabolic specialization of diploid and triploid D. labrax muscle tissue.

\section{Materials and methods}

Production of triploids, somatometrics, and ploidy verification

Triploid (3n) D. labrax were produced by post-fertilization cold shock at $0{ }^{\circ} \mathrm{C}$ for $10 \mathrm{~min}, 5 \mathrm{~min}$ after fertilization (Felip et al. 1997). Larvae of the controls and cold-shocked fish were raised in commercial hatchery tanks $\left(1.6 \mathrm{~m}^{3}\right)$ in duplicates under natural conditions of temperature and photoperiod used for sea bass fry production.

When the fry reached size above $5 \mathrm{~g}, 5000$ fry of each group were size-graded and evenly splitted in two circular tanks $\left(3 \mathrm{~m}^{3}\right.$ water in each) creating two replicates for $2 n$ and $3 n$ fish and reared for a period of 6 weeks. The fish were reared under identical conditions and fed with the same formulated feeds.

After a period of 6 weeks, samples of the diploid and triploid fish were taken and body weight, fillet weight, and filleting yield, was measured to the nearest $0.1 \mathrm{~g}$ in 10 samples from each experimental tank $(n=10$ from each replicate and $n=20$ fish in each group).

Daily-specific growth rate was estimated according to the following equation: 


$$
\operatorname{SGR} \%=\left(\ln \mathrm{BW}_{\mathrm{t} 2}\right)\left(\ln \mathrm{BW}_{\mathrm{t} 1}\right) / \text { days } \times 10 .
$$

From each replicate, fish were anaesthetised in with $40 \mathrm{mg} \mathrm{l}^{-1}$ of clove oil (Perdikaris et al. 2010) and blood samples (100-200 $\mu \mathrm{l})$ from $2 n$ to $3 n$ fish $(n=5$ fish from each replicate tank, total $n=10$ from $3 n$ to $n=10$ from $2 n$ fish) were collected from the caudal vein using heparinized syringes and polyploidy of the triploid group was confirmed by RBC measurements on blood smears stained with methylene blue-eosine stain. Nuclear width $(\mathrm{nW})$ and length $(\mathrm{nL})$ were measured using an Olympus microscope fitted with a video camera and a computer-assisted image analysis system. The nuclear volume (nV) was calculated according to the ellipsis equation:

$$
\text { Vnucleus }=4 / 3 \times \pi \times(a / 2) \times(b / 2) 2
$$

where $a$ is the $\mathrm{nL}$ and $b$ is the $\mathrm{nW}$.

Only fish that were confirmed triploids were included in the biochemical analysis ( $n=6$ for triploid and $n=10$ for diploid).

Biochemical analyses

The DNA and RNA contents of axial muscle tissue were estimated according to the method of Burness et al. (1999) with some modifications as described by Mittakos et al. (2012). Sample of white epaxial muscle was obtained and DNA was extracted using the phenol-chloroform extraction procedure. Samples were digested overnight with $0.1 \mathrm{mg} / \mathrm{ml}$ proteinase $\mathrm{K}$. An equal volume of phenol-chloroformisoamyl alcohol (25:24:1) was added to each digest, and the sample was vortexed and centrifuged for $10 \mathrm{~min}$ at $1700 \mathrm{~g}$. The upper aqueous phase was retained and precipitated with 0.5 volumes of ammonium acetate $(7.5 \mathrm{M})$ and 2 volumes of ethanol $(100 \%)$ and then centrifuged for $3 \mathrm{~min}$ at $1700 \mathrm{~g}$. The pellet was washed in $70 \%$ ethanol and allowed to dry and resuspended in $250 \mathrm{ml}$ of distilled water. DNA purity was assessed at 260/280 nm. Absorbance at $260 \mathrm{~nm}$ was used for quantification.

Total RNA was extracted from briefly homogenised tissue in 10 volumes of homogenisation buffer B (4 M guanidin ethiocyanate, $25 \mathrm{mM}$ sodium citrate, $0.5 \%$ sarcosyl, and $15 \mathrm{mM}$ mercaptoethanol) with a Polytron tissue homogenizer. The extract was frozen at $-80{ }^{\circ} \mathrm{C}$ until analysis. All subsequent procedures were conducted at $0^{\circ}$. The samples were suspended in 1 volume of $2 \mathrm{M}$ sodium acetate ( $\left.\mathrm{pH} 4.0\right), 10$ volumes of buffer-saturated phenol ( $\mathrm{pH} 4.3$ ), and 2 volumes of chloroformisoamyl alcohol solution (49:1) were added to each homogenate and mixed thoroughly between each step. Subsequently, the homogenates were centrifuged for $30 \mathrm{~min}$ at $3000 \mathrm{~g}$. The aqueous phase was retained and mixed with an equal volume of isopropanol and allowed to precipitate at $-20{ }^{\circ} \mathrm{C}$ overnight.

For the enzyme assays, muscle tissue samples ( $n=6$ from each group) were homogenated in an ice-cold medium of $150 \mathrm{mM} \mathrm{KCl}$ in $5 \mathrm{mM}$ MOPS buffer ( $\mathrm{pH} 7.4$ ), using a motor-driven glass homogenizer tube fitted with a Teflon pestle and kept ice cold. Crude homogenates were used for enzyme assays, because the use of centrifugation, to clarify the homogenate, can result in a significant loss of enzyme activity binding to subcellular particles (Vezina and Guderley 1991). Prior to enzyme assays, homogenates were treated with $0.05 \%(\mathrm{v} / \mathrm{v})$ Triton X-100 and each sample was mixed and allowed to stand in ice for about 15 min for full activation of cytochrome $c$ oxidase (Tyler and Nathanailides 1995).

The enzyme assays were performed in duplicate, at $20{ }^{\circ} \mathrm{C}$. The activity of enzymes is given as $\mu \mathrm{mol} / \mathrm{min} /$ mg protein. Cytochrome $c$ oxidase (CCO, EC. 1.9.3.1) activity was assayed by following the decrease in absorbance of reduced cytochrome $c$ at $550 \mathrm{~nm}$, in a medium containing $0.075 \mathrm{M}$ potassium phosphate buffer $\mathrm{pH} 6.8$, and $0.0025 \mathrm{mM}$ ferrocytochrome $c$. Ferrocytochrome $c$ was prepared the day before the assays, in a solution of $1 \%(\mathrm{w} / \mathrm{v})$ cytochrome $c, 10 \mathrm{mM}$ potassium phosphate buffer and $0.1 \mathrm{mM}$ EDTA (pH 7.0), by adding $20 \mathrm{mM}$ potassium ascorbate. Potassium ascorbate was removed by dialysis against an ice-cold medium of Pi-EDTA buffer as above, using three changes of buffer, two during the day and one overnight. The dialysed solution of ferrocytochrome $c$ prepared in this way contained at least $95 \%$ of the total cytochrome $c$ in reduced form (Tyler and Nathanailides 1995). 
Activity of the glycolytic enzyme lactate dehydrogenase (LDH, EC 1.9.3.1) was assayed in a medium of $50 \mathrm{mM}$ potassium phosphate buffer $(\mathrm{pH} 7.0$ ) containing $0.15 \mathrm{mM}$ NADH and $0.60 \mathrm{mM}$ sodium pyruvate (Mittakos et al. 2012).

Total fat contents of fillets were measured in six fish from the $3 n$ fish and 10 fish from the $2 n$ fish according to the Bligh and Dyer (1959) methodology. Fillet moisture content was determined according to the AOAC (1998) method. Protein content was estimated using the Folin-Lowry method (Lowry et al. 1951). Student's $t$ test, $X^{2}$, or one-way ANOVA was applied for statistical analyses.

\section{Results}

Triploid fish exhibited increased nuclear size. The mean ratio of $\mathrm{nL}$ and $\mathrm{nW}$ of $3 n$ and $2 n$ fish was similar to those reported by Felip et al. (1997) for diploid and triploid sea bass, indicating the successful induction of triploidy in the experimental fish of the present work. The effect of triploidy was magnified when comparing the nuclear volumes due to the bi-dimensional nature of this trait (Table 1).

The proximate composition of fish flesh was significantly affected by ploidy. Protein and water content were significantly higher in triploids than in diploids, but $3 n$ fish had lower lipid content (Tables 2 and 6). Growth rate and filleting yield were not affected by ploidy (Table 3).

The nucleic acid content of $3 n$ fish was significantly higher compared to $2 n$ fish, with $3 n$ fish exhibiting about 53\% and 28\% higher DNA and RNA content, respectively. Compared to triploids, diploids exhibited about $17.2 \%$ and $28.7 \%$ higher RNA/DNA and protein/DNA ratio, respectively (Table 4).

Table 1 Verification of triploidy from RBC haemocytological parameters

\begin{tabular}{lrrr}
\hline Nuclear length, width and volume of RBC $(\mu \mathrm{m})$ & $3 n$ & $2 n$ & \multicolumn{1}{l}{ Statistics } \\
\hline $\mathrm{nW}$ & $5.21( \pm 0.11)$ & $4.04( \pm 0.02)$ & $t$ test, $p<0.001$ \\
$\mathrm{~nL}$ & $7.02( \pm 0.04)$ & $4.79( \pm 0.07)$ & $t$ test, $p<0.001$ \\
$\mathrm{nW} / \mathrm{nL}$ & $0.74( \pm 0.01)$ & $0.84( \pm 0.01)$ & $X^{2}, p<0.01$ \\
$\mathrm{nV}\left(\mu \mathrm{m}^{3}\right)$ & $99.27( \pm 4.57)$ & $40.96( \pm 0.79)$ & $t$ test, $p<0.001$ \\
\hline
\end{tabular}

Ratio of $\mathrm{nW}(3 n) / \mathrm{nW}(2 n)=1.31( \pm 0.03)$, ratio of $\mathrm{nL}(3 n) / \mathrm{nL}(2 n)=1.47( \pm 0.02)$

Table 2 Proximate composition of $3 n(n=5)$ and $2 n(n=10)$ D. labrax, axial muscle tissue

\begin{tabular}{lrrrc}
\hline & $3 n$ & $2 n$ & Statistics & $\begin{array}{l}\text { \% of difference in the } 3 n \text { fish, } \\
\text { compared to } 2 n \text { fish }\end{array}$ \\
\hline Fat $(\%)$ & $2.81( \pm 0.23)$ & $3.46( \pm 0.47)$ & $t$ test, $p<0.05$ & $-23.13 \%$ \\
Protein $(\%)$ & $10.59( \pm 0.76)$ & $9.61( \pm 0.34)$ & $t$ test, $p<0.05$ & $+10.19 \%$ \\
Water $(\%)$ & $68.81( \pm 0.61)$ & $66.87( \pm 1.22)$ & $t$ test, $p<0.05$ & $+2.90 \%$ \\
\hline
\end{tabular}

The last column indicates the $\%$ of increased or decreased values observed in the $3 n$ fish

Table 3 Somatometric parameters of triploid $(n=$ ?) and diploid $(n=$ ?) D. labrax juveniles, after a period of 6 weeks

\begin{tabular}{|c|c|c|c|c|c|}
\hline & \multicolumn{2}{|l|}{$3 n$} & \multicolumn{2}{|l|}{$2 n$} & \multirow[t]{2}{*}{ Statistics } \\
\hline & Tank 1 & Tank 2 & Tank 1 & Tank 2 & \\
\hline Initial BW (g) & $5.62( \pm 0.76)$ & $5.52( \pm 0.35)$ & $5.65( \pm 0.45)$ & $5.34( \pm 0.30)$ & ANOVA, $p=0.30$ \\
\hline Final BW (g) & $18.68( \pm 0,97)$ & $18.47( \pm 1.64)$ & $18.31( \pm 1.19)$ & $18.75(1.86)$ & ANOVA, $p=0.32$ \\
\hline SGR (\%/day) & 2.85 & 2.87 & 2.79 & 2.98 & $X^{2}, \mathrm{NS}$ \\
\hline Filleting yield \% & $41.50(1.37)$ & $41.24(1.17)$ & $41.85(2.51)$ & 40.77 (1.91) & $X^{2}, \mathrm{NS}$ \\
\hline
\end{tabular}


Table 4 Nucleic acid (RNA, DNA) content of triploid $(n=6$ fish) and diploid $(n=10)$ D. labrax axial muscle tissue

\begin{tabular}{lrlll}
\hline nucleic acid & $3 n$ & $2 n$ & Statistics & $\begin{array}{l}\text { \% of difference in the } 3 n \text { fish, } \\
\text { compared to } 2 n \text { fish }\end{array}$ \\
\hline RNA $\left(\mu \mathrm{g}^{-1} \mathrm{mg}^{-1}\right.$ tissue $)$ & $17.10( \pm 1.98)$ & $13.30( \pm 1.19)$ & $t$ test $p<0.001$ & $+28.6 \%$ \\
DNA $\left(\mu \mathrm{g}^{-1} \mathrm{mg}^{-1}\right.$ tissue $)$ & $9.36( \pm 0.72)$ & $6.10( \pm 0.8)$ & $t$ test $p<0.001$ & $+53.44 \%$ \\
RNA/DNA & $1.83( \pm 0.06)$ & $2.21( \pm 0.27)$ & $X^{2} p<0.05$ & $-18.2 \%$ \\
Protein/DNA & $1.14( \pm 0.11)$ & $1.60( \pm 0.23)$ & $X^{2} p<0.01$ & $-28.7 \%$ \\
\hline
\end{tabular}

The last column indicates the $\%$ of increased or decreased values observed in the $3 n$ fish in reference to the $2 n$ fish

Table 5 Enzyme activities ( $n=6$ in each group) of cytochrome $c$ oxidase (CCO) and lactate dehydrogenase (LDH) from $3 n$ and 2n D. labrax, axial muscle tissue

\begin{tabular}{lccc}
\hline & $3 n$ & $2 n$ & Statistics \\
\hline $\mathrm{CCO}$ & $4.22( \pm 0.12)$ & $3.89( \pm 0.13)$ & $t$ test $p<0.001$ \\
$\mathrm{LDH}$ & $118.57( \pm 4.44)$ & $99.20( \pm 11.16)$ & $t$ test $p<0.001$ \\
$\mathrm{CCO} / \mathrm{LDH}$ & $0.036( \pm 0.008)$ & $0.040( \pm 0.006)$ & $X^{2} p<0.01$ \\
\hline
\end{tabular}

Enzyme activity for CCO is given in ìmoles of ferrocytochrome $c$ oxidized $\mathrm{min}^{-1} \mathrm{mg}$ protein ${ }^{-1}$, and for LDH as reduction of NADH $\mu$ moles $\min ^{-1} \mathrm{mg}$ protein ${ }^{-1}$. Differences assessed by Student's $t$ test $\left(*_{p}<0 \cdot 001\right)$. Data were arc-sin transformed prior to statistical analysis. Numbers in parentheses indicate standard deviation

The activities of the aerobic metabolism enzyme CCO and the glycolytic LDH of muscle tissue were significantly higher in the $3 n$ fish. Nevertheless, the ratio of these two enzymes was lower in the $3 n$ fish, indicating metabolic difference in the potential for aerobic metabolism in the $3 n$ fish (Table 5).

\section{Discussion}

There was no significant difference in the growth rate of the two groups. This is in agreement with previously published data which indicate that, under culture conditions, diploids and triploids may exhibit similar growth during the first year of their life (Felip et al. 1999). In fact, the maximum triploidy benefits are expected at least after the onset of the sexual maturation and particularly if larger fish are cultured (e.g., $>1 \mathrm{~kg}$ ) as in rainbow trout (Felip et al. 2001, 2009).

Ploidy had no effect on filleting yield. In other words, the total skeletal muscle tissue content was not affected by ploidy. Interestingly, ploidy affected the proximate composition of fish flesh. The main effect of ploidy was on the increased protein (10\% higher) and decreased fat (23\% less) of triploid fish. Differences in the protein content between $2 n$ and $3 n$ fish indicate significant differences in the myofibrillar proteins (myosin, troponin, and tropomyosin). Increased muscle protein and reduced fat in the $3 n$ fish reflects increased total myofiber content of $3 n$ fillets, but provide no information on the effect of ploidy on the growth dynamics, size, and number of individual muscle cells which constitute the axial musculature. The nucleic acid content of skeletal muscle tissue can provide some information for the effects of ploidy on muscle growth. The ratio of RNA/DNA and protein/DNA can be used as indicators of skeletal muscle growth dynamics (Cheek et al. 1971). DNA content reflects the number of cells and RNA the size. Increased DNA content exhibited in the present work by the triploid fish reflected the expected increased DNA content (about 1.5 times more) of $3 n$ fish compared to $2 n$. RNA/DNA was about $17.2 \%$ less in the $3 n$ fish. Apparently, increased DNA content of $3 n$ fish is not resulting in elevated RNA levels (Schmidtke et al. 1976). There is some evidence to suggest that RNA levels are governed by compensatory regulatory mechanism which can reduce transcript levels with cellular RNA governed by genetic regulatory mechanisms (Pala et al. 2008, Swartz 2016). Under conditions of similar RNA degradation rates, differences in the RNA/DNA indicate different protein synthetic capacity of cells, whereas differences in protein/DNA ratios can reflect differences in cell size/growth (Schmidtke et al. 1976). The raised ratio of protein/DNA in the $2 n$ fish (28.7\% higher) can be partially explained by the raised DNA content of $3 n$ fish (about 53\% higher), which was paralleled by a much smaller increase (about 28.6\%) in 
RNA content. In conclusion, differences in the ratio of RNA/DNA reflect the effects of ploidy on DNA content as well differences in myofibril umber and size between the two groups. Assuming that RNA levels are governed by compensatory regulatory mechanism in the $3 n$ fish (Pala et al. 2008, Swartz 2016), the increased RNA content of triploid sea bass provides indirect evidence of muscle hypertrophy in this group with larger cells requiring more RNA (Schmidtke et al. 1976).

In addition to ploidy effects on the nucleic acid content, evidence of ploidy effects on skeletal muscle metabolism was observed in enzyme activities assayed in the present work. Differences in the activity of CCO and LDH indicate differences in the capacity for aerobic and anaerobic metabolism, respectively (Childress and Somero 1979). The activities of CCO and LDH of $2 n$ and $3 n$ fish indicate metabolic specialization differences between the two groups, which may offer some advantages under certain conditions to one of the two groups. For example, the increased activity of LDH may reflect a potential shift towards anaerobic metabolism required under demanding conditions, for example, during burst swimming with higher capacity for anaerobic swimming of triploid fish, but this advantage can be associated with negative consequences on the sustained routine swimming speeds (Virtanen et al. 1990; Marras et al. 2013). Furthermore, summer high water temperatures, coupled with reduced dissolved oxygen levels, conditions which are expected to worsen by the on-going climate change, may create unfavourable conditions for triploids in the summer. This potential seasonal disadvantage of $3 n$ sea bass may be reversed during winter time. The increased CCO activity of $3 n$ fish observed in the present work is in agreement with the reported effects of ploidy on the capacity for cold acclimation of triploid fish (Atkins and Benfey 2008). Increased mitochondrial enzyme content is considered a frequently observed physiological compensatory response of fish cells, responding to limited oxygen diffusion and reaction rates at cold temperatures (Nathanailides et al. 1996). In conclusion, ploidy affected nucleic acid, enzyme content, and proximate composition in D. labrax (Table 6).

The results of the present work indicate significant differences in metabolic specialization of $2 n$ and $3 n D$. labrax skeletal muscle. The European sea bass is widely cultivated at floating sea cages and fish are exposed to challenging winter lows and summer high temperatures. At temperatures below $11{ }^{\circ} \mathrm{C}$, the mitochondrial enzyme content, feeding, and growth of sea bass is reduced and it became lethargic (Trigari et al. 1992; Nathanailides et al. 2010). It would be interesting to investigate the potential ploidy effect on the capacity for thermal acclimation at low winter and high summer seasonal temperatures during the entire production cycle of Mari-cultured European sea bass.

Table 6 Differences (\%) in the biochemical parameters of triploid fish compared to diploids

\begin{tabular}{ll}
\hline Biochemical parameter & \% of increase $(+) /$ decrease $(-)$ in the $3 n$ fish \\
& Numbers in parenthesis indicate the magnitude of difference \\
\hline RNA $\left(\mu \mathrm{g}^{-1} \mathrm{mg}^{-1}\right.$ tissue $)$ & $+28.57 \%$ \\
& $(\times 1.3)$ \\
DNA $\left(\mu \mathrm{g}^{-1} \mathrm{mg}^{-1}\right.$ tissue $)$ & +53.44 \\
& $(\times 1.5)$ \\
RNA/DNA & -18.2 \\
& $(\times 0.8)$ \\
Protein/DNA & -28.75 \\
Fat $(\%)$ & $(\times 0.7)$ \\
& -23.13 \\
Protein $(\%)$ & $(\times 0.7)$ \\
Water $(\%)$ & +10.19 \\
CCO & $(\times 0.9)$ \\
LDH & +2.90 \\
CCO/LDH & $(\times 1.0)$ \\
\hline & +7.82 \\
& +16.33 \\
& -11.11 \\
& \\
&
\end{tabular}




\section{Compliance with ethical standards}

Ethical approval All animal procedures were in strict accordance to the fish welfare recommendations of the Faculty of Veterinary Medicine, University of Thessaly.

Conflict of interest There is no conflict of interest between authors in the publication of this paper.

Open Access This article is distributed under the terms of the Creative Commons Attribution 4.0 International License (http:// creativecommons.org/licenses/by/4.0/), which permits unrestricted use, distribution, and reproduction in any medium, provided you give appropriate credit to the original author(s) and the source, provide a link to the Creative Commons license, and indicate if changes were made.

\section{References}

AOAC (1998) Official methods of analysis of AOAC International, 3rd revision, 16th edn. Association of Official Analytical Chemists International, Gaithersburg

Arndt SKA, Benfey TJ, Cunjak RA (1994) A comparison of RNA concentrations and ornithine decarboxylase activity in Atlantic salmon (Salmo salar) muscle tissue, with respect to specific growth rates and diel variations. Fish Physiol Biochem 13:463-471

Atkins ME, Benfey TJ (2008) Effect of acclimation temperature on routine metabolic rate in triploid salmonids. Comp Biochem Phys A 149:157-161

Benfey TJ (1999) The physiology and behavior of triploid fishes. Rev Fish Sci 7:39-67

Bligh EG, Dyer WJ (1959) A rapid method of total lipid extraction and purification. Can J Biochem Phys 37:911-937

Burness GP, Leary SC, Hochachka PW, Moyes CD (1999) Allometric scaling of RNA, DNA, and enzyme levels: an intraspecific study. Am J Physiol Reg I 277:R1164-R1170

Cheek DA, Holt AB, Hill DE, Talbert JL (1971) Skeletal muscle cell mass and growth: the concept of the deoxyribonucleic acid unit. Pediat Res 5:312

Childress JJ, Somero GN (1979) Depth-related enzymic activities in muscle, brain and heart of deep-living pelagic marine teleosts. Mar Biol 52:273-283

Cimino MC (1974) The nuclear DNA content of diploid and triploid Poeciliopsis and other poeciliid fishes with reference to the evolution of unisexual forms. Chromosoma 47:297-307

Egginton S, Sidell BD (1989) Thermal acclimation induces adaptive changes in subcellular structure of fish skeletal muscle. Am J Physiol-Reg I 256:R1-R9

Felip A, Zanuy S, Carrillo M, Martínez G, Ramos J, Piferrer F (1997) Optimal conditions for the induction of triploidy in the sea bass (Dicentrarchus labrax L.). Aquaculture 152:287-298

Felip A, Zanuy S, Carrillo M, Piferrer F (1999) Growth and gonadal development in triploid sea bass (Dicentrarchus labrax L.) during the first two years of age. Aquaculture 173:389-399

Felip A, Piferrer F, Zanuy S, Carrillo M (2001) Comparative growth performance of diploid and triploid European sea bass over the first four spawning seasons. J Fish Biol 58:76-88

Felip A, Carrillo M, Zanuy S (2009) Older triploid fish retain impaired reproductive endocrinology in the European sea bass Dicentrarchus labrax. J Fish Biol 75:2657-2669

Gonçalves JFM, Hinzmann M, Machado J, Araújo S, Oliveira JC, Ozório RO (2018) Oxidative effect of L-carnitine on energy metabolism in diploid and triploid rainbow trout (Oncorhynchus mykiss): impact on metabolites. Int Aquat Res 10:133-143

Goolish EM, Adelman IR (1987) Tissue-specific cytochrome oxidase activity in largemouth bass: the metabolic costs of feeding and growth. Physiol Zool 60:454-464

Goolish EM, Barron MG, Adelman IR (1984) Thermoacclimatory response of nucleic acid and protein content of carp muscle tissue: influence of growth rate and relationship to glycine uptake by scales. Can J Zool 62:2164-2170

Guderley H, Gawlicka A (1992) Quantitative modification of muscle metabolic organization with thermal acclimation of rainbow trout (Onchorhynchus mykiss). Fish Physiol Biochem 10:123-132

Hochachka PW, Mommsen TP (1983) Protons and anaerobiosis. Science 219:1391-1397

Houlihan DF, Mathers EM, Foster A (1993) Biochemical correlates of growth rate in fish. In: Rankin JC, Jensen FB (eds) Fish ecophysiology. Chapman and Hall, London, pp 45-71

Lowry OH, Rosebrough NT, Farr AL, Randall RJ (1951) Protein measurement with the folin phenon reagent. J Biol Chem 193:265-275

Marras S, Killen SS, Domenici P, Claireaux G, McKenzie DJ (2013) Relationships among traits of aerobic and anaerobic swimming performance in individual European sea bass Dicentrarchus labrax. PLoS One 8:e72815

Maxime V (2008) The physiology of triploid fish: current knowledge and comparisons with diploid fish. Fish Fish 9:67-78

Mittakos I, Ayala MD, López-Albors O, Grigorakis K, Lenas D, Kakali F, Nathanailides C (2012) Muscle cellularity, enzyme activities, and nucleic acid content in meagre (Argyrosomus regius). Can J Zool 90:1270-1277

Nathanailides C (1996) Are changes in enzyme activities of fish muscle during cold acclimation significant? Can J Fish Aquat Sci 53:2333-2336

Nathanailides C, Lopez-Albors O, Abellan E, Vázquez JM, Tyler DD, Rowlerson A, Stickland NC (1996) Muscle cellularity in relation to somatic growth in the European sea bass Dicentrarchus labrax (L.). Aquac Res 27:885-889 
Nathanailides C, Paschos I, Tsoumani M, Perdikaris C, Kapareliotis A (2010) Capacity for thermal acclimation and winter mortality of sea bass Dicentrarchus labrax in freshwater earthen ponds. Ital J Zool 77:23-28

Pala I, Coelho MM, Schartl M (2008) Dosage compensation by gene-copy silencing in a triploid hybrid fish. Curr Biol 18:1344-1348

Perdikaris C, Nathanailides C, Gouva E, Gabriel UU, Bitchava K, Athanassopoulou F, Paschos I (2010) Size-relative effectiveness of clove oil as an anaesthetic for rainbow trout (Oncorhynchus mykiss Walbaum, 1792) and goldfish (Carassius auratus (L.). Acta Vet Brno 79:481-490

Saavedra LM, Quiñones RA, Gonzalez-Saldía RR, Niklitschek EJ (2016) Aerobic and anaerobic enzymatic activity of orange roughy (Hoplostethus atlanticus) and alfonsino (Beryx splendens) from the Juan Fernandez seamounts area. Fish Physiol Biochem 42:869-882

Schmidtke J, Schulte B, Kuhl P, Engel W (1976) Gene action in fish of tetraploid origin. V. Cellular RNA and protein content and enzyme activities in cyprinid, clupeoid, and salmonoid species. Biochem Genet 14:975-980

Somero GN (1973) Thermal modulation of pyruvate metabolism in the fish Gillichthys mirabilis: the role of lactate dehydrogenase. Comp Biochem Phys B 44:205-209

Somero SN, Childress JJ (1980) A violation of the metabolism-size scaling paradigm: activities of glycolytic enzymes in muscle increase in larger fish. Physiol Zool 53:322-337

Suresh AV, Sheehan RJ (1998) Biochemical and morphological correlates of growth in diploid and triploid rainbow trout. J Fish Biol 52:588-599

Swartz SZ (2016) Polyspermic fertilization resulting in multipolarity in a sea star zygote. Mol Reprod Dev 83:375

Trigari G, Pirini M, Ventrella V, Pagliarani A, Trombetti F, Borgatti AR (1992) Lipid composition and mitochondrial respiration in warm and cold adapted sea bass. Lipids 27:371-377

Tyler DD, Nathanailides C (1995) Assaying for maximal activity of cytochrome $c$ oxidase in fish muscle. Basic Appl Myol 5:99-103

Vezina D, Guderley H (1991) Anatomic and enzymatic responses of the three spined stickleback, Gasterosteus aculeatus to thermal acclimation and acclimatization. J Exp Zool 258:227-287

Virtanen E, Forsman L, Sundby A (1990) Triploidy decreases the aerobic swimming capacity of rainbow trout (Salmo gairdneri). Comp Biochem Physiol A 96:117-121

\section{Publisher's Note}

Springer Nature remains neutral with regard to jurisdictional claims in published maps and institutional affiliations. 